\title{
https://doi.org/10.18485/sj.2019.24.1.21
}

РАДОЈЕ Д. СИМИЪ

Универзитет у Београду

Филолошки факултет
Оригинални научни рад Примљен: 27. 11. 2018. Прихваћен: 15. 01. 2019.

\section{НАПОМЕНЕ О СЕМАНТИЦИ И СИНТАКСИ КОМПОЗИЦИЈСКИХ УНИВЕРБАЛНИХ ТВОРЕНИЦА}

\begin{abstract}
Синтакса, по оцени стручњака, не обухвата само конструкције од више међу собом повезаних речи, него се протеже и на сложенице, јер се код ових још увек осећа унутрашње двојство, које допушта и синтаксичко тумачење међуодноса. На грађи из речника̂ аутор је покушао нешто прецизније сагледати тај проблем.

Кључне речи: сложена реч, сложеница, ендонимност/есоцентричност, егзонимност/ексоцентричност, синтаксичка структура, рекција, атрибуција.
\end{abstract}

\section{1. НЕКОЛИКО РЕЧИ УНАПРЕД}

1. Универбацијом се у лингвистици сматра „спајање у неправу сложеницу (фр. composé inproprement dit) ријечи од којих свака задржава своје властито значење”, за разлику од ,атрибутивне или апозитивне сложенице (фр. composé attributif ou appositif) у којима коначно значење није точан зброј саставних ријечи" (Симеон 1969: s. v.). По Симеоновим дефиницијама универбат је дакле неправа сложеница како је он схвата - вишелексемска изговорна сраслица у којој чланови задржавају семантичку аутономију: кућѐвласнӣк власник

*jelenajo@bitsyu.net 
[...] куће [...] (РСJ 2007)1. У обе формације - у сложеној речи и дефиницији - садржане су две исте основе речи 'кућ-' и 'власник', које задржавају своја значења. Разлика је само у формалној структури: генитив кућћ̄ према себи у сложеници има морфолошки друкчије ситуиран тај елеменат, и друкчијег порекла, тзв. везни вокал. Али значење 'кућа' остаје исто.

2. А. Белић не употребљава термин 'универбација', , а не чини ни разлику између правих и неправих сложеница онако како је она дефинисана код Симеона.

a) У својим лингвистичким истраживањима (Белић 1998: 521-524) он праве сложенице не супротставља неправим, већ простим речима: „У томе и јесте, по моме мишљењу, главна природа сложеница: док се у њој осећају саставни делови, дотле имамо праву сложеницу, а чим она изгуби своју двојност, она постаје за нас, за наше језичко осећање проста реч. Зато су Windmühle, Waldbaum, Zimmerherr и многе друге немачке сложенице праве сложенице док словенско медвед у коме се осећа јединствен назив, није то више, иако је дијахронички несумњиво да је то сложена реч". Белић најпре запажа да универбација полилексемских структура није јединствен појам, и посматрајући га у дијахроној перспективи утврђује да у томе постоје бар два ступња: једно су 'праве сложене речи', а друго 'просте речи' настале даљим развојем сложених (отприлике онај који једе мед -> медојед [по Белићу прасл. madhu-ed] -> медвед; исп. диј. међед = мед+јед-).

б) Ни у директним разматрањима о творби сложених речи Белић (2000: 106-108) све ове речи назива 'правим сложеницама', и међу њима чини нека друга појмовна и терминолошка разграничења:

Код свих сложеница, кад се посматрају односи међу деловима, могу бити свега два случаја: или је копулативни однос, када су две речи, које су спојене функцијом према другим речима у реченици, у подједнаком односу између себе, на пр. стӓрма̄лй, стӓр и

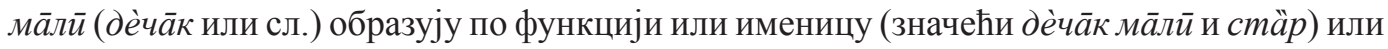
придев који се односи на исту именицу (дакле су везани истом придевском функцијом). Такве се сложенице називају есоцентричним и њих има врло мало у нашем језику; све су остале сложенице ексоцентричне, јер се помоћу њих приписује значење сложенице предметима изван њих. На пр. сто̀кућа 'онај који има сто кућа' (поштар), сто̀нога (животиња) 'што има сто ногу' итд. Таквих сложеница у нашем језику има врло много. Научници их називају различитим именима (у старије време 'релативне сложенице', 'објективне сложенице', 'атрибутивне сложенице' и сл.) [...] док се копулативне сложенице [...] називају индиским називом bahuvrihi (тј. пар, и то само за именице). У првом случају, тј. код ексоцентричних композита, однос међу члановима може бити детерминативан [...] или допунски, падежни [...] Исп. за прве случајеве: брӓтучед, богу̀мил, а за друге да̀нгубити, ку̀пиво̄јска и сл. Ове последње се називају и сложенице са рекцијом.

${ }^{1}$ Пуна дефиниција садржи додатне синонимске елементе: „власник, сопственик куће, зграде".

${ }^{2}$ У новијим студијама о творби речи нисмо наишли на напомене о овој тематици (Бабић 1986; Клајн 2002) 
Белић истиче дистинкције међу самим 'правим сложеницама', и разврстава их у категорију есоцентричних и ексоцентричних, ми бисмо радије рекли: ендонимних и егзонимних. Разлику налази заправо у односима међу деловима сложене речи које он назива синтаксичким. Прве су оне које су „у подједнаком односу између себе” (биће „у симетричном”, одн. равноправном, или речено синтаксичким термином - напоредне), а код ексоцентричних „у подједнаком односу између себе". Међутим, ако смо исправно разумели Белићеве речи, и ако о њима размислимо, пример који аутор наводи не оправдава овакав став:

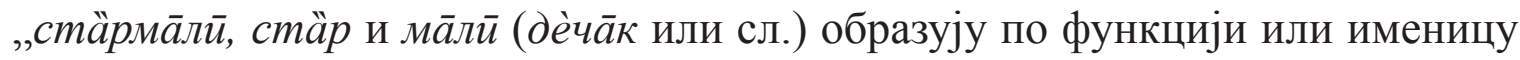
(значећи дѐч $\bar{a} \kappa м \bar{a} л \bar{u}$ и стӓр) или придев који се односи на исту именицу (дакле су везани истом придевском функцијом)". Аутор хоће рећи да стӓрма̄лй значи cmäp и мйлй када у статусу именице значи дечака, или у функцији придевске

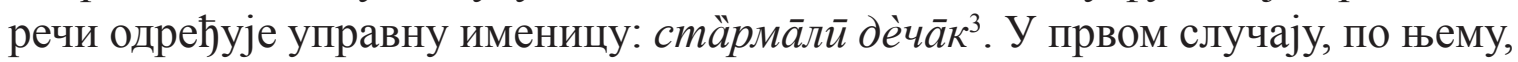
значење је остало у пољу који чине саставнице: 'стармали' = (неко) стар и мали (не исказује се носилац особина посебно, већ 'стармали'), у другом пак значење 'дечак' стоји ван семантичког поља 'стар и мали', којем ови попут придевских речи приписују особине из свог семантичког садржаја. Ствар међутим не стоји сасвим тако. Наиме, 'стармали' у именичкој функцији има заправо два семантичка поља, од којих једно покривају саставнице сложене речи, а друго је идентификабилно метафором ('стармали' $=$ [рано сазрео $]$ дечак). Јављају се два значења, од којих је једно дезактуелизовано и потиснуто из првог плана у позицију мотивног блока, Друго је значење актуелно: 'дечак'. Нема сумње да је слагањем речи померен је - сем граматичког статуса: поименичени придеви -> именица - такође и семантички центар из поља облеженог сложеницом 'стармали' ('стар а мали') у поље ван примарног ('дечак') У другом случају 'стармали' значи просто 'стар и мали' (боље 'а мали'), док је 'дечак' само атрибуирана величина, и није саставни елеменат значења сложенице. Рекло би се, према Белићевим интерпретацијама, да у овом случају имамо есоцентрично значење сложенице, а у првом случају - ексоцентрично. Али, наиме, есоцентричност - или јасније: ендонимност, - тиче се односа међу саставницама, ексоцентричност - или егзонимност. - Наша анализа међутим показује да је прво поимениченост, и друго, помереност и избледелост значења саставница сведочи о егзонимности, одн. ексоцентричности, У другом случају значење сложенице није померено јер се задржава у истом семантичком пољу.

в) Битан је за нашу анализу још један моменат, који Белић (1998: 104), на основу разлике међу 'правим' и 'неправим' именицама - на следећи начин објашњава:

${ }^{3}$ У РСЈ (2007) лексикограф се не обзире на Белићеве дистинкције него даје једнозначну дефиницију: „који је по годинама млад, а по владању или изгледу стар” - која упућује на придевски статус сложенице (ознака 'који' припада придевима, а 'онај који' карактерише реч као именицу). 
[...] Именице означавају претставу предмета са свим особинама његовим које оне обележавају непосредно, даном речју. Тако исто придеви значе особину предмета коју они непосредно обележавају; све су остале речи - и прави глаголи, и заменичке, и прилошке и одношајне речи - по значењу синтагматске. Оне дају не непосредно, својим знаком оно значење које садрже у себи, већ посредно.

Значење по Белићу представља способност упућивања не на садржај као нешто компактно и монолитно, него „претставу предмета са свим особинама његовим", дакле скуп састојака сабраних и издвојених тако да омогућују примену речи на 'ствари' из свог семантичког поља. Тако схваћен, појам значења није статична велична, већ сваки пут кад је употребимо, она сабира специјалне и за ту прилику прикладне елементе потребне за препознавање садржаја исказа, идентификацију онога што именица значи. И поред тога што свака реч тежи сопственом идентитету, али све док се са тако утврђеном констелацијом реч задржава у свом семантичком пољу, она задржава есоцентрични карактер, ендонимни; када у семантички скуп елемената продру семе из других поља, ендонимија постепено уступа место ексоцентричности, одн. егзонимији. Ендонимију можемо назвати унутрашњим именовањем, а егзонимију спољашњим.

г) Слажући се с Белићем у основним идејама кад говори о 'правим' и 'неправим им' именицама, морамо ипак напоменути да о питању 'посредног' и 'непосредног' упућивања на садржај - није сасвим у праву. Ако именица предмете назива активирајући асоцијације на особине његове, онда се не може рећи да је то 'непосредно именовање'. Узећемо још једну Белићеву мисао која ће нам помоћи да дођемо до правог његовог става, као и о односу 'неправих' именица према 'правим' (1998: 46):

То су несамосталне речи у самосталној употреби. Чим се несамосталне речи почну употребљавати, оне су [...] условно реализоване. То значи да се њима одређује неко лице или неки предмет који се јавља као носилац извесне особине или радње. То није једно одређено лице или један одређени предмет, наравно у оном смислу у којем су то праве именице, већ ма које лице које носи дату особину или ма који предмет извесне врсте. Напр. 'копач' онај који копа, 'зло' оно што је зло".

„Тако - по Белићу (1998: 34) - ако узмемо реч 'камен', онда претстави о камену ништа не недостаје".

д) Али у специјалној употреби ова именица поново активира однос према особинама које се у названом предмету садрже латентно:

Ако речемо за човека да је 'камен': „он је камен”, - то значи „он је чврст” или „он је хладан”. Очевидно је да су чврстина и хладноћа, и много штошта друго, саставни делови претставе „камен” који се у даном случају из претставе излучују по жељи онога ко говори. Ако речемо „он је [као] стена, то значи он је енпомичан, постојан и сл.”

Управо Белићеве речи потврђују оно што смо рекли у претходним пасусима. Поједини елементи општег значења могу бити садржани и посебној употреби речи, овде пренесени на други 'предмет': „он је камен” нема више за 
центар називања све 'особине' (структуралисти би рекли: дистинктивне црте) из семантичког поља речи, већ су им придружене друге, оне које карактеришу 'човека' као свесно, друштвено опредељено биће.

ђ) С тим у вези Белић (1998: 37) размишља о семантичким процесима који се дешавају у разноврсној употреби речи, и о кретању речи између 'праве' и 'неправе' лексичке вредности, одн. лексичког потенцијала речи, како Белић мисли:

Речи које значе реалне предмете претстављају збир особина сједињених у претстави извесног предмета. У теорији се може рећи да се у несамосталној употреби самосталне речи које значе реалне предмете могу свести у онолико засебних значења колико се засебних особина садржи у њиховој претстави. Најпростији случај излучивања тих значења претставља предикативна употреба самосталних речи јер се њоме на известан начин за извесно време субјекат (=самостална реч) увек ближе одређује, а свако одређивање значи откривање извесног броја унутрашњих момената дате речи (које се налазе у збиру њених могућих значења и њихових односа, тј. у њихову потенцијалу) - оном речју, или унутрашњим моментима речи којима се ближе одређивање врши. Ако је та одредбена реч именица, онда се из целокупности њених особина издвајају оне које су потребне да се њима открије каква латентна особина или страна речи која се одређује [...]

Разлика између латентних и објављених момената на којима почива значење речи, како видимо из Белићевих размишљања, и како је стварно стање значења речи - моменат је који се може схватити динамички, као кретање у семантичкој бази речи, као промоција неких саставних елемената 'представе' или као њихова атрофија: повлачење у сферу латентних елемената који чине 'унутрашњи потенцијал' речи. Ова дубинска природа речи отвара перспективу и на односе који оне иза себе крију, и омогућава да пратимо хијерархију међу правим и неправим сложеницама. То ћемо учинити анализирајући 'праве' и 'неправе' сложене речи - праве и неправе именице и придеве.

е) Новија тумачења семантике речи полазе од посматрања ове појаве из различитих углова. један од методолошких приступа јесте тзв. 'компоненцијална' анализа', која у великој мери личи на Белићеву расправу о 'унутрашњем потенцијалу' и његовој структури. Но 'компоненцијалисти' друкчије гледају на 'једнозначне', 'монсемантичне', а друкчије на 'вишезначне', 'полисемантичне' речи.

а) Из подробне расправе коју с тим у вези води Р. Драгићевић (2007: 67) проистиче да компонентама код 'једнозначих', 'моносемантичних ' речи ваља схватити значењске 'дистинктивне црте', 'семе'. Ако нпр. реч 'човек' посматрамо као једнозначну, онда јој одговара дефиниција: „живи организам, сисар из реда примата који је постигао највиши развојни ступањ, друштвено биће које мисли, говори и располаже способношћу да ствара оруђа и да се њима служи у процесу рада". И сам је лексикограф, сем идентификације сема, успоставио неки ред међу њима, јер дефиниција коју посматрамо има заправо два дела. Први обухвата биолошке моменте ('живи организам' итд.) 
а други духовне ('друштвено биће' и др.). Остале се семе групишу око те две језгрене компоненте - и такви односи у ствари чине базу за хијерархизовану класификацију: примарне и секундарне, централне и периферне, потенцијалне и реалне или сл. ${ }^{4}$. Мало смо заправо збуњени тим односима јер се јављају два семантичка језгра. Али чињеница да се она по правилу паралелно активирају говори ипак о јединству семантичке структуре дате речи, док остале њима придружене семе остају у позадини, чине резервни садржај. Ипак се дешава да 'човек' у употреби ову двојност може превазићи хијерархизацијом двеју језгрених сема: Он је човек - већином значи „човек позитивних духовних особености", док су физичке запостављене.

б) Код 'полисемантичних' речи односи су много компликованији. Узећемо опет лексему 'човек' и посматрати је као полисемичну. Горе дефинисано значење (или значења) описано је не као једино него само као једно од више њих. Нпр. дефиниција под два гласи: „зрео, одрастао мушкарац”; под три: „особа, личност као носилац високих моралних и карактерних особина”; под четири: „припадник једнога народа, земље сталежа, друштвеног реда”; под пет: „нар. муж, супруг”, итд. Прво што је уочљиво у овим односима, јесте факат да наведена значења нису потпуно изолована једно од другога као што би се очекивало, већ су на неки начин повезана. Тако „зрео, одрастао мушкарац” упућује у првом реду на телесно стање, док ,личност као носилац високих и моралних [...] особина - на духовно, итд. Тиме се успоставља такође хијерархија, јер се полисемија показује као хијерархизована појава: две гране којима као да се шири семантичко поље. као да ничу из два значења сједињена у значењу под један. Друго што ваља нагласити јесте да ако говоримо о семантичком пољу или пољима, онда је питање како се то може схватити код полисемантичних речи. Чини ли полисемантичка реч јединствено семантичко поље, или је издељена у више њих. Наша анализа упућује на ужу везу међу значењима, те је јасно да она на неки начин чини јединство, а не прост збир самосталних значења (в. наше објашњење уз гоње дефиниције).

в) Но како у вези са реченим посматрати сложене речи? Очито је да морамо утврдити однос међу семама и њиховим скуповима, односно о пољима и њиховом обиму и садржају. 'Богочовек' обједињује основе двеју посебних речи које се изговарају и пишу као једна лексема. Ова се реч може дефинисати као 'бог и човек's, као 'божји човек' или сл. Прва интерпретација подвллачи паралелизам и равноправност двају значења, која су ступила у ужи однос, али не и у међузависност. У другом пак случају елеменат 'бого-' прешао је у

${ }^{4}$ Драгићевић помиње и друге класификације, што за нас значи да су односи међу 'семама' врло разноврсни (в. даље наш став).

${ }^{5}$ У РСЈ (2007) забележена прва дефиниција: „онај који је, по хришћанском учењу, и бог и човек”. - У РСАНУ (1957. д.), поред наведене, постоји и дефиниција: „2. човек са божанским својствима". 
положај зависног члана формације. Можемо овде, по угледу на синтаксичаре, говорити о комбинацији и интеграцији, с тим што 'бог и човек' показује да комбинација овде није проста узајамност, већ је чврста веза. У првом случају с тим у вези можемо говорити о атхерентном, а у другом о инхерентном односу: основе у првом случају равноправно деле заједничко семантичко поље, док су у другом срасле у целину.

3. М. Стевановић (1991 I: 399 и д.) проширује, али у извесном смислу и мења Белићева схватања и утврђује:

Сложенице су, дакле, обично некадашње синтагме, а ређе и некадашње целе реченице. Али сви повезани скупови не постају сложеницама једноставно, само ако дуго стоје, тј. ако се дуго употребљавају у тој чврстој међусобној вези, него је потребно да у тим скуповима речи (синтагмама), односно у реченицама, настану извесне промене, да обично дође, прво, до промене њихова значења, затим до промене у акценту и квантитету и до промене у самом гласовном склопу њихову. Сложеница Београд, нпр., постала је ово што је сад када је њом именован град престао да буде оно што ове две речи употребљене заједно али одвојене једна од друге значе, тј. када је престао да буде, боље рећи кад је престао да се осећа као бео град, и када се везом ових двеју речи почело означавати место које више није било бело (а није чак морало бити ни град).

Хијерархија коју успоставља Стевановић обрнута је оној код Симеона: правим се овде сматрају Белићеве ексоцентричне, а есоцентричне су неправе сложене речи. Том хијерархијом отворен је видик и на могућност схватања универбације као вишестепеног процеса, и класификације грађе по том критерију. Један је правац посматрања из оцртане перспективе тај да се постави хијерархија 'ексоцентризације'. Примера ради ако̀бо̄гда̄, данѝно̄ћ или врстѐлез семантички су сасвим измештени, јер прва значи „надам се, по свој прилици, вероватно. - Акобогда брзо ћемо се вратити кући. нар. куда, камо. Акобогда? Идем у сватове” (РСЈ 2007), друга је „врста љубичице, маћухица Viola tricolor”, а трећа „шаљиво име за измишљени празник (дан у који се не ради)” (РСАНУ 1957. и д.: s. v. $)^{6}$. То би био највиши домет сложеничке ексоцентризације, одн. универбације на семантичком плану. Значи, постоји могућност и структурне хијерархизације, јер нпр. према наведеним речима постоје сложенице као злостава/злостављање мучење, или 'злочин' тешко кривично дело (убиство, разбојништво, повреда, крађа и сл.). Овде није најпре јасан статус и семантичка вредност првог дела 'зло-'. Ако је она придевска, онда 'зло-' има статус квалификатора другог дела: злодело = зло дело (рђав, зао поступак). Ако је пак именичка, онда је најближа интерпретација односа синонимном синтагмом 'зло у виду дела (поступка)', 'зло на делу', одн. и обрнуто: дело као зло. У сваком је случају ситуација несумњиво есоцентрична, али није једнозначно одредљив однос међу члановима сложенице, јер је допуштено двојство тумачења. Ако су мотивне речи именице, онда је однос равноправан, а огледа се у двосмерности објашњења. Али кад на уму имамо претпостављени ток

${ }^{6}$ Тамо врстѐлези. Код Стевановића врзтѐлез: (1991: 400). 


\section{'слагања речи', онда морамо обрнути смисао хијерархије, и друкчије схватити однос 'правих' и 'неправих'. Видећемо у прегледу грађе ${ }^{7}$ како ствари стоје на семантичком простору различитих типова сложеница.}

\section{2. ПРЕГЛЕД ГРАЪЕ}

\section{1. Именице}

1. Према горе описаној теми размотрићемо грађу с обзиром на степен есоцентризације значења. Прво ћемо навести примере за конструкције које су најблаже захваћене поменутим процесом. Врло су бројне па наводимо само део грађе:

Аустроӱгарска̄ двојна држава Аустрије и Угарске

блаิгда̄н/блӓгда̄н празнични дан, празник

блӓгословв изражавање жеље за нечије добро и срећу [...]

вёлегра̄д велики град

велепо́сед велики посед, велико пољопривредно имање, имање које се налази у нечијем поседу

во̀доток ток воде, водени ток, водена струја

дво̀пев певање у два гласа

двоेчас два наставна часа спојена заједно

домоупра̀витељ управитељ дома

дрвопрѐрада индустријска прерада дрвета

дірворёд ред дрвећа [...]

гороेсеча $(2)$ сечење дрва у шуми, сечење шуме [(1) онај који сече дрва у шуми, шумски радник]

злато̀рог дивокоза златних рогова

живо̀дер стрводер, шинтер [...]

живото̀пис опис живота неке личности, биографија

земљопо́сед земљишни посед, земљишна имовина

зёмљотре̄с подрхтавање Земљине коре, потрес, трус

зло̀воља рђаво расположење, незадовољство, срџба

злӧко̄б зла судбина, несрећа, коб

злона́мера зла, рђава намера

зло̀патња страдање, злопаћење, патња

зло̀срећа зла срећа, зао удес, несрећа, јад [...]; особа зле среће, несрећник, -ца

зна̀тижеља жеља да се нешто сазна, радозналост, љубопитљивост

зубо̀боља бол у зубима

гӓсоме̄тар апарат за мерење утрошеног гаса, плина, плиномер

детеуби́ство/децоуби́ство убиство детета, односно деце, чедоморство

дубино̀мер справа за мерење дубине (обично воде)

дӱборе̄з техника украшавања дрвених површина [...], дрворезбарство [...]

дйгобра̄д човек дуге браде, брадоња

дӱгобрк човек дугих бркова, бркајлија

Евроа́зија заједнички назив за Европу и Азију

${ }^{7}$ Углавном смо прегледали Николићев једнотомник (РСЈ 2007: А-И); тамо где Николић не наводи реч, а нађена је другде или смо се ми сетили, гледали смо у РМС (1967-1967), а по изузетку и у РСАНУ (1959. и д. Види изворе грађе). 
еврокомунйзам комунизам европског типа

еко-кожа ?

електроакуेстика грана електротехнике коа се бави проучавањем претварања звучних трептаја у електричне и обрнуто

електроанали́за квантитативна хемијска анализа на основу електролитичког издвајања елемената из раствора њихових соли

електроेвод спроводник електричне с трује [...]

електродина̀мика грана науке о електрицитету која проучава кретање електри-

цитета и механичке и магнетне појаве изазване њиме

електроенѐргија електрична енергија...

етнобиоло̀гија наука која проучава биолошка својства народа

етномузиколо̀гија грана музикологије која се бави проучавањем музичког фол-

клора, народне музике

етнопсихоло̀гија наука која се бави проучавањем психологије појединих народа и племена

жаро̀пек/жа̄ропек врелина, жега, припека

живо̀бара мочвара, баровито земљиште, пишталина

живо̀ждер онај који једе живо месо

жа̂р-птйца рајска птица, феникс

животопи́сац писац животописа, биограф

жито̀род род, принос жита

жуто̀во̄љка птица певачица [...] са жутим перјем на грудима, стрнарица

жуто̀лик жут, пожутео у лицу; жућкаста изгледа

жутоेног који је жутих ногу

жуто̀пёрка жутовољка [...]; риба [...] жутих пераја

звездо̀лик који има облик звезде, звездаст

зймзелен који и зими има зелену боју лишћа

жу̀чово̆д жучни канал, жучна цевчица

за̀уман који је ван памети, непојмљив, безуман

звездозна́нац познавалац звезда, астроном

земљо̀власнйк власник земље, земљопоседник

земљоде́лац земљорадник

земљоेра̄днйк пољопривредни радник који се бави обрадом земље, ратар, тежак злаัтовёз вез рађен златном жицом [...]; повез књиге са повезом у злату

злато̀врана птица кричалица Coracias garrula

злӧслӯт/зло̀слутнйк онај који слути зло, несрећу

зло̀твор онај који некоме чини зло, непријатељ, душманин; злочинац, зликовац зуботѐхнича̄р стручњак [...] за техничке послове у зубарству

игло̀зуб морска риба Chaliodus Slohani [...]

Гледајући на однос дефиниције према дефинисаној речи ${ }^{8}$, закључићемо да су речи које их чине заправо синоними.

a) У извесним случајевима на неки начин се у дефиницији - неизмењени или нешто дручије уобличени - понављају лексички елементи из назива: 'домоуправитељ': управитељ дома; 'дрворед': ред дрвећа; 'земљопосед': земљишни посед, 'водоток' ток воде, водени ток, водена струја итд. Свака компонента сложенице задржава своје изворно значење. Синтаксички однос

${ }^{8}$ У анализи ћемо по правилу полазити од лексикографске дефиниције, а тамо где то не сматрамо оправданим, даћемо напомене. 
такође видан из дефиниције: увек је први део у односу атрибутске одредбе у односу на други.

Али 'атрибутска одредба', нпр у синтагми земљишни посед подразумева приписивање односа према земљи(шту). А у 'земљопосед' 'дрворед' и сл. није прецизирано који тип међуодноса основа постоји: посед земље: земљишни), посед у виду земље, или како друкчије (можда: земља као посед?); одн. 'ред дрвећа' или 'дрвеће у реду'. Двосмерност односа у ствари значи синтаксичку антиципацију атрибута у полузависни назив, тј. измену и атрофију сентаксичког момента у универбату.

б) Код 'дрвопрерада' дефиниција проширена: индустријска прерада дрвета, тако да обухвата само индустријску, а не и занатску делатност око израде предмета од дрвета. Тако је дошло до померања значења дефиницијске семантике у односу на сложеницу, и ремећења есоцентричности, али у минималној мери. Тако је и у 'знатижеља' жеља да се нешто сазна и сл.

в) Следе примери 'благдан' празнични дан, празник, 'земљотрес' подрхтаване Земљине коре, потрес, трус; 'злокоб' зла судбина, несрећа, коб; 'злопатња' страдање, злопаћење, патьа. У дефиницији је додуше садржана по једна истокорена лексема у делу сложенице, али је други део замењен синонимом друкчијег облика. У првом случају нпр., 'број' одговара другој компоненти сложенице, а први део је замењен посебном лексемом; 'дан' се понавља у дефиницији, док према 'благ' стоји 'празнични'; у земљотрес према 'земљо-' стоји истокорена реч 'Земљин', док су остали елементи истозначни са '-трес', али другог постања. У следећем према 'зло-' 'зла' и сл. стоји у другом делу 'судбина', синонимна реч са 'коб' (РСЈ 2007: „по народном веровању, унапред одређен ток догађаја, судбина (обично зла").

г) У случајевима као 'злочин' тешко кривично дело (убиство, разбојништво, повреда, крађа и сл.); 'зловоља' рђаво расположење, незадовољство, сриба; 'злостава', 'злостављање' мучење - међу синонимима нема морфолошко-лексичких додира. Али пошто су одредница и дефиниција синонимне, нема сумње да се ради о есоцентричном односу. Синтаксичка страна универбације, међутим, из дефиниције по правилу није спознатљива. Једино у директној анализи самог унвербата 'злочин' могло би се простим умовањем претпоставити да је први део зависан у односу на други: 'злочин': 'зло чињење' или пак други 'зло чинити', што зависи од претпостављених мотивних речи.

ђ) Ваља на крају обратити пажњу на пример 'злосрећа'. Сем дефиниције помоћу синонима, забележили смо и другу, друкчијег типа: особа зле среће, несрећник, -ца. (1) Лексема 'човек' своје значење уклињава између онога што значи одредница и што значи синонимна формација 'зле среће'. Формом 'зла срећа' има сада статус приписивача особине централној лексеми 'човек', а ова 
сада стоји према 'злосрећи'. У сваком случају видна је помереност основног значења ('злосрећа' - 'човек'), као и синтаксичка физиономија универбата у односу на мотивну конструкцију 'зла срећа'.

2. Слично управо анализираном случају формиране су сложенице у следећим примерима:

вётрока̄з направа која се окреће под дејством ветра и показује његов правац висино̀мер справа за мерење висине

вӧдовод систем грађевина, направа и цевовода за снабдевање (насеља, индустрије и др.) водом [...]

водоко̀тлић посуда, резервоар у коме се скупља и из кога се испушта вода за испирање клозетске шоље

вӧдоскок млаз воде који шикља увис [...]

гӓсовод уређај, цевовод за спровођење гаса, плиновод

гороेсеча (1) онај који се бави сечењем дрва у шуми, дрвосеча

грӯдобра̄н насип, бедем, зид или који други заклон од непријатељске ватре [...]

даљино̀мер инструмент за мерење удаљености

дймовод димњак; цев димњака

доेбротвор онај који чини добра дела [...], доброчинитељ

дрво̀сеча онај који сече дрва у шуми, шумски радник који ради на сечи шуме

дрвостру̀га̄p занатлија који струже дрво [...]

дужино̀мер справа за мерење дужина [...]

а) 'Водовод' је систем грађевина [...] за снабдевање [...] водом, 'водокотлић' посуда, резервоар у коме се скупља и из кога се испушта вода [...] итд. 'Вода' се у оба случаја појављује и у сложеници и у дефиницији, али као споредни детаљ у објашњењу значења, док други део сложенице нема ни синонимне речи, већ уместо '-вод' стоји 'систем грађевина', одн. уместо 'котлић' 'посуда, резервоар'. По томе судећи, сложенице које смо управо анализирали долазе једним делом у ред егзонима, ексоцентричних сложеница. Други пак део има ендонимски карактер - по уобичајеној терминологији: есоцентрични.

б) Дефиниције по себи указују на синтаксичке односе у сложеници. Ако 'систем грађевина' одговара елементу сложенице '-вод', онда овај алудира на глаголско порекло 'водити', док 'водо-' означава саму воду. Дакле: 'воду водити'. У случају да је анализа тачна, рећи ће да први део сложенице одговара објекту глагола, дакле: у допунском је односу према другом делу. Но 'водовод' може бити и друкчије схваћен: као вода у вођењу, или вода која се води, коју воде; што значи да је први део сложене речи синтаксичка доминанта, а други има атрибутску функцију. Сведок да синтаксички односи нису једнозначно одредљиви.

3. Апсолутно су есоцентричне, ендонимне сложенице у следећим примерима

А̀ра̄нђеловда̄н дан када се слави св. Арханђел [...]

Госпођйнда̄н в. Госпојина 
Ђуิрђевда̄н црквени и народни празник посвећен св. Ђорђу Йвањда̄н црквени и народни празник посвећен Ивану (Јовану) Крститељу [...] Јо̀вањда̄н православни црквени празник посвећен св. Јовану Мйтровда̄н црквени и народни хришћански празник посвећен св.Димитрију [...] Пѐтровда̄н цркв. празник св. Петра и Павла [...]

Без обзира што код 'Госпођиндана' дефиниција садржи само 'В. Госпојина' (у РСЈ погрешно 'в.'), ипак је јасно значење сложенице: 'дан Велике Госпође (Богородице)'. Остали су случајеви једнозначно протумачиви као спој придевске и именичке основе, где је придевски део у одредбеној функцији према именичком.

4. Специфична је природа следећих композита

дво̀лом двојно преламање светлосних зрака $[. .$.
дво̀звук сазвучје од два звука
дво̀меч меч, такмичење између два учесника, две екипе
дво̀прег кола са запрегом од два коња
дво̀стих строфа од два стиха, дистих
дво̀тачка интерпункцијски знак, две тачке
дӧбробйт срећа, благостање [...]
вйшебо̄ј такмичење у више дисциплина [...]
жйвопйс сликарство (обично старо, фресака и икона)

а) Лексеме 'дволом', 'двозвук', 'двомеч', 'двотачка' и сл. ${ }^{9}$, састоје се од бројевне основе и везног вокала -о-: 'дво-' и именичке основе ${ }^{10}$. 'Двотачка' је потпуно транспарентна, тј. ендонимна, есоцентрична, а синтаксички однос међу деловима је једносмерно зависан: 'две тачке' обједињују два номинатива множине (двојине) и равноправни су. Али с обзиром на стање у облицима двојине, тумачење ове сложенице може бити и одговарајуће са другим наведеним бројевним сложеницама: 'дво-' је исто што и два, а 'тачка' је еквивалент генитива 'тачке'. Први и потоњи пример чувају есоцентрични карактер ('дволом' <- двапут ломити; 'двомеч' два меча). Средњи пример инсистира додуше на двозвучју, али за дефиницију има реч 'акорд', која према двозвук стоји као управна реч према зависној сложеници: спој два звука. Што се тиче синтаксичке структуре, ако је у основи прве сложенице глаголска синтагма 'двапут ломити', онда је аналогно томе 'дво-' у функцији прилошке одредбе, дакле у односу зависног дела сложенице. Уколико пак допушта тумачење као 'два лома', онда први део представља синтаксичку доминанту, док је 'звук' у зависном допунском статусу.

б) 'Двопрег' и 'двостих' дефинисани су као егзоними: кола са запрегом од два коњ а, одн. строфа од два стиха. Могуће је и друкчије тумачење 'два

${ }^{9}$ Исп. и друге сложенице са бројем као првим делом: пето̀ба̄нка новчаница вредности од пет банки [...], пётобо̄j некадашње такмичењежена у пет атлетских дисииплина [...]; трӧзвйк акорд, сазвучје од три звука [...] - тро̀зуб оруђе са три зуба, зупиа, трокраке виле.

10 'Дволом' се може тумачити и глаголским пореклом: 'лом' = ломити. 
(коња) у запрези', одн. 'два стиха у строфи', а то мења синтаксичку физиономију: 'дво-' има положај ствари: јер 'два коња', одн. 'два стиха' имају сада као целина језгрени положај у констукцији.

в) 'Добробит' и 'живопис' састоје се од основе прилошког карактера у првом делу, и глаголског другог елемента ${ }^{11}$.

5. Малобројна је група сложеница које су, по слову речничке дефиниције - потпуно изгубиле везу са мотивним речима:

вӧдосе̄к кљун на броду

гӧроцвёт род зељастих отровних биљака [...]

добро̀јутро срећа, добро [...]; зло, несрећа [...]

зймзелён биљка пузавица Vinca maior

a) 'Водосек' по себи садржи асоцијације на бродски кљун, али дефиниција на то не упућује. Ако је мотивацијска структура 'сећи воду', онда је први део у допунксом односу према другом. Али ако је полазиште 'секач воде' или сл., онда је први део у одредбеној функцији према другом.

б) 'Гороцвет' и 'зимзелен' такође су у себи мотивисане формације: 'цвет у гори' или 'горски цвет', одн. 'зими зелено' или 'зимско зеленило'. Опет свака интерпретација сугерира своју синтаксичку структуру.

в) Посебну структуру има 'добројутро', где је једнозначан упут на атрибутско-именичку синтагму.

г) Али сва горња објашњења важе за примарну семантичку структуру, која после померања из композиционих разлога бивају сасвим потиснута у позадину.

6. Посебно место на листи наших примера припада сложеницама са предлогом као првим делом:

беза́кон безакоње

бѐзбрига 1. безбрижност, добро расположење; безбрижан живот. 2. безбрижна особа, весељак

бёзбро̄j велика множина, мноштво, огроман број

бёздан дубока провалија чије се дно не може сагледати, понор, амбис [...]

бёскра̄j бескрајан простор, бескрајно пространство, бескрајност

вансезо́на време ван сезоне

вйшеб̄̄j такмичење у више дисциплина...

до̀вод довођење, допремање [...]

до̀воз допремање превозним средством, довожење, транспорт

дӧглёд 1. оптички инструмент за посматрање далеких предмета, дурбин, далекозор.

2. простор обухваћен погледом, видик, видокруг; домашај погледа

дӧгово̄p разговор, саветовање ради доношења заједничких одлука; заједничка одлука, споразум [...]

${ }^{11}$ Остављамо по страни проблем мотивацијске структуре код 'живопис', тј. могућност тумачења као редуктивну форму према 'живописати'. 
доेгон догоњење, дотеривање (стоке)

дӧдйр непосредни контакт [...]

дӧзйв дозивање, глас којим се неко дозива

до̆зйд (нема у речницима) дозиђивање; дозидак, накнадно дозидани део

до̀каз чињеница, одн. скуп чињеница којима се доказује нешто [...]

а) 'Безакон' и 'безбрига', дефинисани су као 'безакоње' и 'безбрижност', дакле истозначницом са мало помереном творбеном структуром. Обе речи упућују на одсуство закона, односе неуређене законима или сл. Ендонимија је основна особеност двеју твореница, а структура синтаксичких односа одговара оној у мотивној синтагми 'без закона', 'без бриге': предлог се понаша као регенс.

б) 'Безброј' је 'велики број', што подсећа на иронијски 'обрт' у супротно значење од садржаног у сложеници ('без' = много или сл.).

в) 'Вансезона' време ван сезоне и 'вишебој' такмичење у више дисииплина $[\ldots .$.$] - ексоцентрични су утолико што се у првом реду односе на 'време' и на$ 'такмичење', а 'ван сезоне' и 'више дисциплина' представљају објашњење назива. Конструкција коју чине сложеница као одредница и дефиниција као њено тумачење синтаксички су симетричне ('вансезона' - време [...]). Таква је и сама сложеница асиметрична, јер предлог има статус регенса, а именица ректума.

г) Остали примери међусобно су слични: сложеница је састављена од предлога и редукованог елемента - 'до-вод', 'до-воз' итд. При томе 'вод' и 'воз' алудирају на врсту активности, дакле глаголског су порекла. Чини се да ови елементи и нису именског већ глаголског порекла, па се заправо не ради о слагању, већ о редуктивној творби: 'довод'< доводити, 'довоз' < довозити и сл.

\section{2. Придеви}

1. Придевске речи датога структурног модела далеко су малобројније од именица, и далеко мање разноврсности. Ево примера за први модел:

бакарноцровен тамноцрвен као бакар

Наведени пример, заједно са додатним: зеленкастоплав, мркожут, плавозелен, светлочрвен, тамнозелен, ирвеносмеђ, спада у групу речи „за обележавање нијанси (боја нпр.)"12. Дефиниција 'тамноцрвен као бакар', а сличне би биле и остале, упућује заправо на истозначност компоненти сложенице и дефиниције: 'бакарноцрвен' ирвен као бакар. Ендонимичност или есоцентричност у вези је са једносмерношћу синтаксичких релација: прва компонента има одредбену функцију у односу на другу.

${ }^{12}$ Правопис МС (2010: 87). Додатне примере позајмили смо отуда јер се иначе у речницима не бележе, вероватно услед неприхватања правила о писању ових формација. 
2. И други тип придевских сложеница ретко је бележен:

врто̀глав који изазива вртоглавицу

зло̀гук који прориче зло, несрећу; злослутан

Формације су сличне, али међу њима има и разлика. Погледаћемо их изблиза. 'Вртоглав' који изазива вртоглавииу, 'злогук' који прориче зло, несрећу; злослутан. Једна од компоненти је глаголског порекла, а друга именичког. У првом случају глаголски део је глаголски, а однос према другом делу је однос регенса према ректуму ('прориче зло'), док је у другом '-гук' на другом месту, и има позицију доминанте. Обе су сложенице у основи ендонимне, есоцентричне.

3. Следе формално слични случајеви, али са извесним разликама:

бабо̀лик који је као баба, сличн баби [...]

бледо̀лик који има бледо лице; [...] који је бледог, слабог сјаја

вуко̀лик који је налик на вука [...]

жабо̀лик који личи на жабу

мило̀лик који је лепе спољашњости, који изгледа лепо, мило [...]

младо̀лик кији који има изглед младе особе, који је по изгледу млад

црвено̀лик који је црвена лица, црвен у лицу, румен

човеко̀лик који је сличан човеку

Примери као 'баболик' који личи на бабу, 'златолик' који личи на злато, који је као злато и њима слични у првом делу сложенице имају именски елемент, а у другом '-лик', који је идентификабилан као именица 'лик' ('има лик тај и тај'), или пак као део глаголског корена 'личити', како и дефиниција сугерира. У оба случаја друга саставница сложенице синтаксички је управни део, док други има подређени положај. Сложенице су по значењу есоцентричне.

5. Велика је група сложеница са првим делом мотивисаним придевском речју, и други именичком:

голо̀брад који нема браде, сасвим млад [...]

голо̀рук који је голих, обнажених руку [...]

голо̀стуб који је без зеленила, оголео (о стаблу дрвета или о брду, планини)

голо̀трб који је гола трбуха [...]

дуго̀брад који има дугу браду

дуго̀брк који је дугих бркова

дуго̀грив који има дугу гриву

дуго̀длак који има дуге длаке

дуго̀ув/дуго̀ух који има дугачке, велике уши [...]

жуто̀брад који је жуте браде

жуто̀брк који има жуте бркове

жуто̀глав који има жуту главу

злато̀зуб који има златне зубе

злато̀кос који има косу боје злата

злато̀крил који је златних, златастих крила

злато̀лик који личи на злато, који је као злато 
Све су форме једнообразне, све есоцнетричне, и код свих је први део у служби атрибутске одредбе другог.

6. Сложенице са бројевним првим елементом сличне су структуре као и код именца (в. горе).

дво̀дом који се састоји од два скупштинска дома [...]

дво̀зуб 1. који има два зуба, два крака [...]; (2) двозубица. козји рогови

дво̀кљун који има два кљуна

дво̀крил двокрилан, који има два крила

дво̀ног двоножан који има две ноге

дво̀ок који има два ока

дво̀рог који има два рога

дво̀стран који има две стране [...]

дво̀струк који се састоји од два струка, две нити [...]

дво̀ух двоушни који има два уха [...]

дво̀члан који се састоји од два члана

'Дводом' је од два дома, 'двозуб' са два зуба, 'двокљун' са два кљуна итд. Све су наведене лексеме сложене од 'дво-' и одговајуће именице. Пошто 'два' у бази има број са функцијом атрибута, онда је по граматичкој физиономији сложеница ендонимна, и са синтаксички асиметричним односом делова.

7. Преостала нам је група сложеница са предлошким првим делом и именичким другим (нашли смо примере само за предлог 'без'):

бѐзбрад који је без браде, голобрад, ћосав

бѐзбрк који је без бркова, голобрад

бѐзглав који је без глав, који нема главе, обезглављен

бѐздан који је без дна,

бѐзлик безличан

бѐзног који је без ноге или ногу

бѐзуст који је без уста

бѐзух/бѐзув који је без једног или без оба уха

бѐсан који је без сна, који се проводи без сна [...]; који не спава, будан

'Безбрад' је без браде, 'безбрк' без бркова, 'бездан' без дна итд. Ендонимност, есоцентричност, прва је особеност ових форми, а друга је рекцијска структура у којој је предлог у позицији управног дела, а именски елемент зависног члана.

\section{ИЗВОРИ}

Правопис МС 2010: Правопис српскога језика, Нови Сад: Матица српска.

PМC 1967-1976: Правопис српскохрватског књижевног језика, св. 1-6, Нови Сад: Матица српска. 
РСАНУ 1959. и д.: Речник српскохрватског књижевног и народног језика, књ. 2, Београд: САНУ.

PCJ 2007: Речник српскога језика, Нови Сад: Матица српска.

\section{ЛИТЕРАТУРА}

Бабић 1986: Stj. Babić, Tvorba riječi u hrvatskom književnom jeziku, Zagreb: Jugoslavenska akademija znanosti i umjetnosti i Globus.

Белић 1998: А. Белић, Општа лингвистика (I/1-2), Београд: Завод за уџбенике.

Белић 2000: А. Белић, Универзитетска предавања из савременог српскохрватског језика, Београд: Завод за уџбенике.

Драгићевић 2007: Р. Драгићевић, Лексикологија српског језика, Београд: Завод за уџбенике.

Клајн 2002: И. Клајн, Творба речи у савременом српском језику, Београд: Завод за уџбенике.

Симеон 1969: R. Simeon, Enciklopedijski rječnik lingvističkih naziva, Zagreb: Matica hrvatska.

\section{NOTES ON SEMANTICS AND SYNTAX OF COMPOSITION UNIVERSAL COMPOUND}

\section{Summary}

The author tried to give an explanation of the state and processes on the structure of the dictionary and the author tried to look at this problem more precisely.

Key words: complex word, compound, endonymity/esocentricity, exonymity/exocentricity, syntax structure, reaction, attribute. 